Makalah

Manjemen Pendidikan

"Karir dalam dunia Pendidikan"

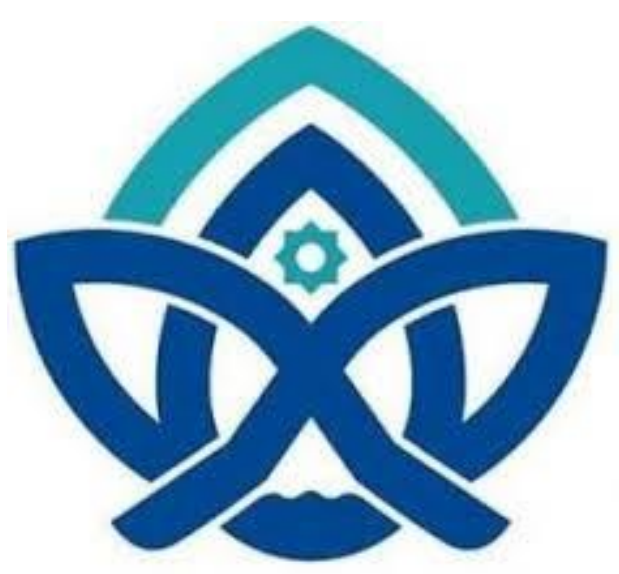

Dosen Pengampu : Samsu, S.Ag, M.pd.I, Ph.D

\title{
PAI 3A
}

Kelompok 2 :

1. Adiya (20118013)

2. M. Mahfuz Putra (201180005)

3. Rini Hamdani Wati (201180032)

Universitas Islam Negeri Sulthan Thaha Saifuddin Jambi

Fakultas Tarbiyah dan Keguruan

Pendidikan Agama Islam 


\section{DAFTAR ISI}

Judul

Daftar isi

BAB 1 PENDAHULUAN

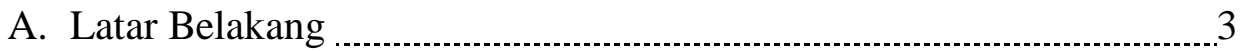
B. Rumusan Masalah ..................................................................... 3
C. Tujuan

BAB 2 PEMBAHASAN

A. Bimbingan karir di Sekolah Dasar ..................................................... 4

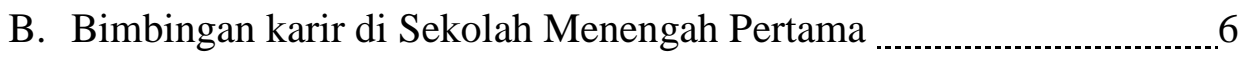

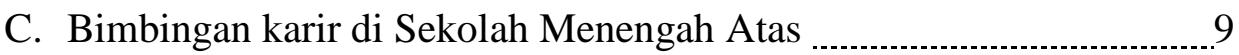

D. Bimbingan karir di Perguruan Tinggi …….....................................

BAB 3 PENUTUP 15

A. Kesimpulan

B. Saran

DAFTAR PUSTAKA 16 


\section{BAB I}

\section{PENDAHULUAN}

\section{A. Latar belakang}

Pendidikan karir adalah pengalaman-pengalaman pendidikan terencana yang memfasilitasi pengembangan karir seseorang. Bimbingan karir merupakan salah satu jenis bimbingan yang berusaha membantu siswa dalam memecahkan masalah karir untuk memperoleh penyesuaian diri yang sebaik-baiknya, baik pada waktu itu maupun pada masa yang akan datang.

Masalah-masalah pribadi yang dihadapi siswa apabila tidak dapat ditangani, diselesaikan dan dituntaskan dengan baik akan mengakibatkan munculnya permasalahan sosial. Sebagaimana yang dijelaskan dalam persoalan masalah pribadi sebelumnya yaitu di lingkungan keluarga, lingkungan sosial masyarakat dan di sekolah.

\section{B. Rumusan Masalah}

1. Bagaimana bimbingan karir di tingkatan SD ?

2. Bagaimana bimbingan karir di tingkatan SMP ?

3. Bagaimana bimbingan karir di tingkatan SMA ?

4. Bagaimana bimbingan karir di tingkatan perguruan tinggi ?

\section{Tujuan}

1. Untuk mengetahui bagaimana bimbingan karir di SD.

2. Untuk mengetahui bagaimana bimbingan karir di SMP .

3. Untuk mengetahui bagaimana bimbingan karir di SMA.

4. Untuk mengetahui bagaimana bimbingan karir di perguruan tinggi. 


\section{BAB II}

\section{PEMBAHASAN}

\section{A. Bimbingan Karir di Sekolah Dasar}

\section{Ruang lingkup bimbingan karier di sekolah dasar}

ruang lingkup BK karier di SD merupakan seluruh yang mencakup tentang isi bimbingan konseling karier, intinya di mana ada manusia disitu ada bimbingan dan konseling tentang karir

Isi bimbingan karier untuk kelas-kelas rendah (kelas 1, 2 dan 3) sebagai berikut :

Mengenalkan perbedaan antarkkawan sebaya,

$>$ Menggambarkan perkembangan diri siswa

$>$ Menjelaskan bahwa bekerja itu penting sesuai dengan tuntutan lingkungan

Isi bimbingan karier untuk kelas-kelas tinggi (kelas 4, 5 dan 6) sebagai berikut :

Menjelaskan manfaat mencontoh orang-orang yang berhasil

$>$ Melatih siswa menggambarkan kehidupan dimasa yang akan datang

$>$ Melatih siswa melihat hubungan antara minat dan kemampuan. ${ }^{1}$ (Rohimah, 2018)

\section{Tujuan bimbingan karier di Sekolah Dasar}

Secara rinci tujuan bimbingan karier di sekolah dasar adalah :

- Dapat menilai dan memahami dirinya sendiri, terutama yang berkaitan dengan potensi yang ada dalam dirinya, mengenai kemamuan, minat, bakat, sikap dan cita-citanya

- Menyadari dan memahami nilai-nilai yang ada didalam dirinya dan yang ada dalam masyarakat

\footnotetext{
${ }^{1}$ Umi Rohimah, bimbingan karir untuk peserta didik di sekolah dasar, Vol.16, 2018, hal:271-272.
} 
- Para siswa dapat merencanakan masa depannya serta menemukan karir dan kehidupannya yang serasi dan yang sesuai.

\section{Dasar bimbingan karier di Sekolah Dasar}

Di dalam sosial masyarakat kerap kita jumpai, beberapa individu cenderung bertanggapan bahwa terlalu dini untuk memberikan bimbingan karir di sekolah dasar. Pendidikan yang diikuti masih bersifat umum, belum mengarah pada jurusan atau bidang tertentu. Individu yang menganut pandangan ini cenderung kebanyakan perencanaan untuk masa depan yang lebih baik jika diberikan apabila di sekolah menengah tingkat pertama atau sesudahn. Hal tersebut bertitik tolak dari pandangan bahwa penyiapan anak untuk memasuki dunia kerja tidak dapat dilaksanakan dalam tempo yang sesingkat-singkatnya, melainkan memerlukan perencanaan yang matang godaan waktu yang cukup lama peneyelenggaraan bimbingan karier di sekolah dasar bukanlah untuk menggantikan bimbingan dan konseling secara keseluruhan, pengetahuan tentang diri, pengetahuan tentang pendidikan dan pekerjaan di masa yang akan datang, serta pengembangan dasar-dasar pembuatan keputusan oleh peserta didik, umumnya dipandang sebagai hal yang sangat penting diberikan di sekolah dasar. ${ }^{2}$ (maliki, 2016)

\section{Tahapan dan perkembangan Karakteristik siswa Sekolah}

\section{Dasar}

Semua aspek perkembangan manusia (sosial, fisik, emosi dan pendidikan) saling berkaitan tak terkecuali perkembangan karir. Perkembangan karir merupakan perkembangan dari manusia, karena :

\footnotetext{
${ }^{2}$ Maliki, bimbingan konseling disekolah dasar, Jakarta, PT fajar interpratama:2016, hal:159-160.
} 
a. Perkembangan terjadi sepanjang hidup manusia. Hal ini dapat digambarkan dalam batas-batang kematangan yang merujuk kepada tahap perkembangan yang dicapai.

b. Perkembangan individu dipengaruhi oleh factor pembawaan dan lingkungan. Ini berarti bahwa factor psikologis, sosiologis, pendidikan, ekonomis, dan fisik berpengaruh terhadap perkembangan individu.

c. Perkembangan adalah proses kontinu. Perkembangan individu dapat dibantu melalui intervensi seawall mungkin dan berlangsung sepanjang hidup.

d. Perkembangan individu mencakup diferensiasi dan integrasi konsep diri dan presepsi tentang dunianya. Bimbingan karir sebagai salahsatu bentuk intervensi perkembangan individu dan berfungsi preventif maupun kuratif.

e. Perkembangan individual, sehingga adanya keragaman individual. Program intervensi termasuk bimbingan karir harus memperhatikan keragaman individual tersebut. ${ }^{3}$ (Syarif, 2012)

\section{B. Bimbingan Karir di Sekolah lanjutan tingkat pertama (SMP)}

\section{Pengertian anak SMP}

Sekolah Menengah Pertama yang disingkat dengan SMP merupakan jenjang pendidikan dasar SD yang memasuki anak pada usia 13-15 tahun pada pendidikan formal di Indonesia setelah lulus sekolah dasar (atau sederajat). Sekolah menengah pertama ditempuh dalam waktu 3 tahun, mulai dari kelas 7 sampai kelas 9. Saat ini Sekolah Menengah Pertama menjadi program Wajar 9 Tahun (SD, SMP).

Anak usia Sekolah Menengah Pertama (SMP) dapat dikategorikan sebagai anak usia remaja awal. Pada umumnya

\footnotetext{
${ }^{3}$ Kemali Syarif, Bimbingan karier di Sekolah Dasar, Vol.4, 2012, Hal:203-204.
} 
ketika usia Sekolah Menengah Pertama (SMP) adalah masa remaja awal setelah mereka melalui masa-masa pendidikan Sekolah Dasar. Masa remaja awal atau masa puber adalah periode unik dan khusus yang ditandai dengan perubahan-perubahan perkembangan yang tidak terjadi dalam tahap-tahap lain dalam rentang kehidupan. ${ }^{4}$ (Hadiarni, 2009)

bimbingan karir di SMP merupakan kelanjutan dari bimbingan karir di SD, melalui guru pembimbing siswa mendapatkan berbagai informasi tentang karir sehingga dapat membina sikap dan apresiasinya terhadap jenis pendidikan, jenis pekerjaan, dan menelusuri hubungan antara kerja dan waktu luang, memperluas minat kerja, serta memberikan berbagai informasi tentang pekerjaan sehingga memunculkan kesadaran siswa untuk menentukan pilihan pekerjaannya dimasa datang sesuai dengan bakat dan minat yang dimilkinya. ${ }^{5}$ (Prayitno, 1997)

\section{Karakteristik siswa SMP}

a. Siswa berusia antara $12 / 13-15 / 16$ tahun

b. Tugas-tugas pokok yang harus dicapai anak, yaitu :

- Mengenal kemampuan, bakat, minya, serta arah kecendrungan karir

- Mengembangkan pengetahuan dan keterampilan untuk pendidikan lanjutan

- Mengenal gambaran dan mengembangan sikap pribadi yang mandiri

- Mengarahkan diri pada peranan sosial sebagai pria atau wanita

c. Perkembangan kemampuan berfikir anak sudah pada tahap operasional formal. Dimana anak sudah mulai berfikir secara

\footnotetext{
${ }^{4}$ Hadiarni, Konseling Karir, Batusangkar: STAIN Batusangkar Press, 2009, hal:184.

${ }^{5}$ Prayitno, pelayanan bimbingan dan konseling sekolah lanjutan tingkat pertama, jakarta:ikrar mandiri, 1997, hal: 68.
} 
abstrak, namun masih perlu bantuan dengan contoh-contoh konkrit dalam kehidupan sehari-hari

d. Berada pada tahap perkembangan remaja, sedang mengalami masa pubertas dan mencari identitas diri. ${ }^{6}$ (Tarmidzi, 2011)

\section{Tujuan umum dan tujuan khusus bimbingan karir di SMP}

a. Tujuan umum

Tujuan umum bimbingan karir di SMP adalah memberikan ksempatan kepada siswa untuk melibatkan diri secara aktif dalam suatu proses yang dapat mengungkapkan berbagai macam karir. Melalui proses tersebut diharapkan siswa menyadari dirinya, kemampuannya, dan hubungan antara keduanya dengan berbagai karir dalam masyarakat.

b. Tujuan khusus

- Memahami lebih tepat tentang keadaan dan kemampuan diri para siswa

- Membina kesadaran terhadap nilai-nilai yang ada pada diri pribadi siswa

- Mengenal berbagai jenis sekolah lanjutan tingkat menengah atas (SMA/MA)

- Mengenal berbagai jenis pekerjaan. ${ }^{7}$ (Walgito, 2010)

\section{Fungsi bimbingan karir di SMP}

a. memberikan arahan kepada siswa agar mempunyai wawasan awal yang obyektif tentang pendidikan lanjutan dan lapangan pekerjaan

b. memberikan bekal tambahan melalui masa peralihan yang sistematis dari status siwa menjadi anggota masyarakat yang produktif

\footnotetext{
${ }^{6}$ Tarmidzi, Pengantar Bimbingan dan Konseling, Medan: Perdana Publishing, 2011, Hal:120

${ }^{7}$ Bimo Walgito, Bimbingan dan Konseling Studi dan Karir, Yogyakarta: CV andi offset, 2010, hal:202.
} 
c. memberikan kesempatan untuk mengenal serta membina sikap, minat, nilai terhadap dunia kerja. ${ }^{8}$ (Gladding, 2012)

\section{Bimbingan karir di sekolah lanjutan tingkat atas (SMA)}

Siswa SMA berada pada rentang usia 17-22 tahun yaitu masa remaja akhir, yang pada perkembangannya mereka dihadapkan pada berbagai masalah yang harus dipecahkan diantaranya penentuan karirnya. Pada tahap ini individu diharapkan mulai merencanakan masa depan karirnya sebagai persiapan memasuki dunia kerja.

Berdasarkan tahap perkembangan karir pada usia 17-22 tahun ini merupakan tahap eksplorasi yang diawali sejak individu memiliki kesadaran bahwa pekerjaan merupakan bagian dari kehidupannya. Setiap orang harus bekerja dan untuk bekerja harus mempersiapkan diri dengan sebaik dan sedini mungkin. Salahsatunya yaitu dengan pendidikan dan latihan.

Di sekolah permasalahan-permasalahan pribadi (individu, sosial, akademik, dan karir) menjadi tanggung jawab seluruh lembaga sekolah, termasuk orangtua dan siswa, salahsatu lembaga yang terkait dan bertanggungjawab secara formal adalah Bimbingan dan Konseling (BK). Sebagai guru BK harus berperan dan membantu siswa dalam mencapai tingkat perkembangan optimal, baik dalam mengatasi masalah pribadi, akademik, maupun karir berdasarkan tugas perkembangan dan potensi-potensi individu. ${ }^{9}$ (Hidayati, 2014)

\section{Prinsip-prinsip pelakasanaan bimbingan karir di SMA}

a. Seluruh siswa hendaknya mendapat kesempatan yang sama untuk mengembangkan dirinya dalam percapaian karirnya secara cepat semua siswa memiliki hak yang sama untuk mengembangkan diri dan merencanakan karir

\footnotetext{
${ }^{8}$ Samuel T. Gladding, Konseling Profesi Yang Menyeluruh, Jakarta: PT. Indeks, 2012, hal: 60.

${ }^{9}$ Novi wahyu hidayati, pengaruh layanan informasi studi lanjut terhadap perencanaan karir siswa, Vol.1, 2014, hal:94-95
} 
Setiap siswa hendaknya memahami bahwa karir itu adalah sebagai suatu jalan hidup, dan pendidikan adalah sebagai persiapan dalam hidup. Bimbingan karir meberikan pemahaman kepada siswa dalam berkarir, bahwa dalam setelah lulus, mereka mebutuhkan suatu tempat dan karya untuk mengaplikasikan ilmu yang telah diterimah dibangku sekolah.

b. Siswa secara keseluruhan hendaknya dibantu untuk memperoleh pemahaman tentang hubungan antara pendidikannya dan karirnya kelak.

c. Setiap siswa hendaknya memilih kesempatan untuk menguji konsep, berbagai peranan dan ketrampilannya guna mengembangkan nilai-nilai dan norma-norma yang memiliki aplikasi bagi karir di masa depannya.

d. Program Bimbingan Karir di sekolah hendaknya diintegrasikan secara fungsional dengan program bimbingan dan konseling pada khususnya. Program materi bimbingan karir dalam penyampaiannya diintegrasikan dengan materi bimbingan konseling. Hal ini dilakukan karena bimbingan karir merupakan bagian dari bimbingan konseling.

e. Program bimbingan karir di sekolah hendaknya berpusat di kelas, dengan koordinasi oleh pembimbing, disertai partisipasi orang tua dan kontribusi masyarakat. ${ }^{10}$ (Putri, 2018)

\section{Tujuan Pelaksanaan Bimbingan Karir di SMA}

Tujuannya adalah membantu siswa dalam pemahaman dirinya dan lingkungannya, dalam pengambilan keputusan, perencanaan, dan pengarahan kegiatan-kegiatan yang mengarah kepada karir dan cara hidup yang memberikan rasa kepuasan karena sesuai, serasi dan seimbang dengan dirinya dan lingkungannya. Sedangkan

\footnotetext{
${ }^{10}$ Rani mega putri, pengaruh layanan informasi bidang bimbingan karir dalam perencanaan karir siswa kelas XII IPA di SMA Negeri 1 indralaya selatan, Vol.16, 2018, hal:12.
} 
tujuan khusus yang menjadi sasaran bimbingan karir di SMA, di antaranya:

a. Agar siswa dapat meningkatkan pengetahuan tentang dirinya sendiri (self concept). Pemahaman diri (konsep diri) adalah merupakan citra diri sendiri. Hal ini nantinya sebagai langkah awal dalam menentukan arah pilih karir yang tepat bagi siswa sehingga tercipta adanya sikap kemandirian siswa dalam memilih karir yang sesuai dengan pemahaman dirinya.

b. Agar siswa dapat meningkatkan pengetahuannya tentang dunia kerja. Pemahaman tentang dunia kerja meliputi pemahaman tentang informasi berbagai persyaratan penerimaan dalam dunia kerja, isi serta sifat suatu lapangan kerja, situasi pekerjaan termasuk dalam aspek sosial, fisik, administrasi, masa depan suatu pekerjaan, organisasinya, serta gaya hidup dalam suatu jabatan dengan dirinya.

c. Agar siswa dapat mengembangkan sikap dan nilai diri sendiri dalam menghadapi pilihan lapangan kerja serta menghadapi hambatan-hambatan yang mungkin timbul yang disebabkan oleh dirinya sendiri dan faktor lingkungan, serta mencari jalan untuk mengatasi hambatan-hambatan tersebut.

d. Agar siswa dapat meningkatkan ketrampilan berpikir agar mampu mengambil keputusan tentang jabatan yang sesuai dengan dirinya dan tersedia dalam dunia kerja. Melalui bimbingan karir siswa akan diarahkandalam mengenal diri dan kemampuannya untuk memahami diri dan senantiasa mampu meningkatkan kemampuannya, melatih dalam merencanakan karirnya sehingga dengan demikian siswa menjadi terlatih dan bersikap dewasa dalam berpikir dan merencanakan karirnya. ${ }^{11}$ (Abu Bakar, 2011)

\footnotetext{
${ }^{11}$ Siti rahmaniah abu bakar, pelaksanaan bimbingan karir bagi siswa SMA sebagai persiapan awal memasuki dunia kerja, Vol.1, 2011, hal: 141.
} 


\section{Bimbingan Karir tingkat Perguruan Tinggi}

Perguruan tinggi adalah salahsatu lembaga pendidikan yang mempunyai tingkatan tertinggi di Indonesia, perguruan tinggi secara umum memiliki sembilan sistem utama untuk mendukung proses bisnis utama berupa pendidikan, penelitian dan pengabdian kepada masyarakat. Salahsatu sistem pada perguruan tinggi tersebut adalah alumni dan karir. ${ }^{12}$ (Setiawan \& Riyanti, 2018) Kepemimpinan jangan dipandang sebagai jabatan pasif, melainkan harus berperan sebagai suatu jabatan yang terlibat dalam suatu tindakan memenuhi pembentukan struktur dalam interaksi, sebagai bagian dari proses pemecahan masalah. ${ }^{13}$ (Rusmini) Adapun masala-masalah yang sering dihadapi yaitu :

\section{Masalah pribadi sosial}

Masalah pribadi yang sering dialami adalah :

a. Masalah pribadi

- Merasa malas untuk melaksanakan ibadah : shalat, shaum, dan amal shaleh lainnya

- Kurang memiliki kemampuan untuk bersabar dan bersyukur

- Masih memiliki kebiasaan berbohong

- Masih memilki kebiasaan menyontek

- Kurang motivasi untuk mempelajari agama

b. Masalah sosial

- Kurang menyenangi kritikan orang lain

- Kurang memahami etika pergaulan

- Merasa malu untuk berteman dengan lawan jenis

\footnotetext{
${ }^{12}$ Ridwan setiawan dan Riyanti, perancangan sitem informasi pengelolaan alumni perguruan tinggi, Vol.15, 2018, hal:85.

${ }^{13}$ Rusmini. S.A, Manajemen dan Kepemimpinan Pendidikan, hal:43-44.
} 
- Kurang mampu menyesuaikan $\operatorname{diri}^{14}$ (khalilah, 2017)

\section{Masalah Pendidikan\}

Pendidikan pada hakekatnya merupakan upaya untuk mengarahkan perkembangan manusia itu agar menuju ke arah yang baik, yang menjadi tekanan perhatian pendidikan adalah perkembangan kepribadian manusia atau segi mental-spiritual psikologis bukan segi jasmaniah saja, seperti diketahui hakekat manusia itu merupakan satu kesatuan jasmaniah rohaniah.

Kegagalan dalam studi bukan hanya disebabkan karena kesalahan di dalam memilih jurusan studi saja, melainkan mungkin juga disebabkan karena kekurangmampuan dalam menyesuaikan diri, cara belajar yang salah, sikap yang salah terhadap diri sendiri.

Segala problem yang diutarakan di atas tidak dapat hanya dibiarkan saja. Akan tetapi perlu di atasi, setidak-tidaknya dikurangi. Apabila sebelumnya kepada konseli diberikan pelayanan konseling yang tepat, mungkin problem tersebut tidak terjadi. Karena dalam konseling tidak hanya tahap-tahapan konseling yang harus di perhatikan tetapi perlu adanya Proses konseling yang baik antara konselor dan konseling.

\section{Masalah Karir}

Membahas tentang karir juga membahas tentang masa depan. Sehingga untuk pencapaian karir yang baik masa depan yang cerah perlu ada perencanaan usaha yang matang terutama dalam proses belajar sebagai modal dalam meniti karir yang baik. Pendidikan karir adalah pengalaman-pengalaman pendidikan terencana. ${ }^{15}$ (Hidayat \& Sumarto, 2018)

\section{Penyelesaian Masalah}

\footnotetext{
${ }^{14}$ Emmi khalilah, layanan bimbingan dan konseling pribadi sosial dalam meningkatkan keterampilan hubungan sosial siswa, Vol.1, 2017, Hal:51-52.

${ }^{15}$ Hidayat dan Sumarto, urgensi pembukaan unit layanan pendidikan bimbingan dan konseling (BK) di setiap program Studi fakultas tarbiyah dan pendidikan UIN Sulthan thaha saifuddin jambi, Vol.2, 2018 hal : 80-83.
} 
Menurut Abdul Latif (1999), dalam kamus matematik masalah dimaksudkan sebagai 'sesuatu yang memerlukan penyelesaian, perkara, ataupun persoalan yang memerlukan jawaban' dari segi etimologinya, istilah 'problem' dalam bahasa inggris itu berasal dari bahasa Greek 'Problema' yang berasal pula dari bahasa proballein yang membawa maksud seuatu yang dicampakkan (ballein) ke depan (pro) yang menjadi sumber keresahan, kesulitan dan kerisauan yang perlu ditiadakan.

Penyelesaian masalah dan pengambilan keputusan merupakan dua hal yang perlu dierlukan oleh seorang pemimpin dalam menyelesaikan persoalan yang dihadapi oleh organisasi. Karena itu, sebelum penyelesaian masalah yang dihadapi oleh sekolah dan pengambilan keputusan dilakukan, kepala sekolah selaku pemimpin harus mengenal masalah yang dihadapi oleh sekolah, menentuka kepiawaiannya dan mengumpulkan informasi terhadap masalah yang dihadapi, serta melakukan penyelesaian masalah secara bertahap.

Penyelesaian masalah dan dan pengambilan keputusan saling berkaitan sebagai bagian proses yang sama, sebagian besar keputusan dibuat untuk menyelesaikan masalah dan sebagian masalah memiliki ruang untuk dilakukan solusi, suatu keputusan mesti dilakukan dan juga diambil. ${ }^{16}$ (Samsu, 2015)

\footnotetext{
${ }^{16}$ Samsu S, Pengaruh Delegasi, Reward Dan Motivasi Kepala Sekolah Terhadap Prestasi Kerja Guru (Studi Pada Sd/mi, Sltp, Dan Slta Kota Jambi). Al-Fikrah: Jurnal Kependidikan Islam IAIN Sulthan Thaha Saifuddin, 2015, hal: 34-35.
} 


\section{BAB III}

\section{PENUTUP}

\section{A. Kesimpulan}

Pendidikan karir adalah pengalaman-pengalaman pendidikan terencana yang memfasilitasi pengembangan karir seseorang. Bimbingan karir merupakan salah satu jenis bimbingan yang berusaha membantu siswa dalam memecahkan masalah karir untuk memperoleh penyesuaian diri yang sebaik-baiknya, baik pada waktu itu maupun pada masa yang akan datang.

\section{B. Saran}

Dalam sebuah pendidikan sebuah bimbingan karir sangat dibutuhkan untuk siswa maupun mahasiswa untuk itu jika kalian menjadi guru ada baiknya untuk mengajarkan atau membimbing siswa supaya mengenal lebih mengenal tentang dunia luar ataupun dunia kerja. 


\section{DAFTAR PUSTAKA}

Abubakar, S. R. (2011). Pelaksanaan Bimbingan Karir Bagi Siswa SMA Sebagai Persiapan Awal Memasuki Dunia Kerja. Selami, 1(34).

Gladding, T.S. (2012). Konseling Profesi Yang Menyeluruh. Jakarta: PT.Indeks.

Hadiarni. (2009). Konseling Karir. Batusangkar: STAIN Batusangkar Press.

Hidayat, H. (2018). Urgensi Pembukaan Unit Layanan Pendidikan Bimbingan dan Konseling (BK) di Setiap Program Studi Fakultas Ilmu Tarbiyah dan Pendidikan UIN Sulthan Thaha Saifuddin Jambi. Jurnal Al-Ashlah, 2(2).

Hidayati, N. W. (2016). Pengaruh Layanan Informasi Studi Lanjut terhadap Perencanaan Karir Siswa. Edukasi: Jurnal Pendidikan, 12(1).

Khalilah, E. (2017). Layanan Bimbingan dan Konseling Pribadi Sosial dalam Meningkatkan Keterampilan Hubungan Sosial Siswa. JIGC, 1(1).

Maliki. (2016). Bimbingan konseling di sekolah dasar. Jakarta: PT fajar interpratama.

Prayitno. (1997). Pelayanan bimbingan dan konseling sekolah lanjutan tingkat pertama. Jakarta: Ikrar mandiri.

Putri, R. M. (2018). PENGARUH LAYANAN INFORMASI BIDANG BIMBINGAN KARIR DALAM PERENCANAAN KARIR SISWA KELAS XII IPA DI SMA NEGERI 1 INDRALAYA SELATAN. WAHANA DIDAKTIKA, 16(1).

Rohimah, U. (2018). Bimbingan Karir untuk Peserta Didik di Sekolah Dasar. Cendekia: Jurnal Kependidikan Dan Kemasyarakatan, 16(2)

Rusmini, S. A. (2014). MANAJEMEN DAN KEPEMIMPINAN PENDIDIKAN. 
Samsu, S. (2015). Pengaruh Delegasi, Reward Dan Motivasi Kepala Sekolah Terhadap Prestasi Kerja Guru (Studi Pada Sd/mi, Sltp, Dan Slta Kota Jambi). AlFikrah: Jurnal Kependidikan Islam IAIN Sulthan Thaha Saifuddin, 6.

Setiawan, R., \& Riyanti. (2018). perancangan sitem informasi pengelolaan alumni perguruan tinggi. 15(2).

Syarif, K. (2012). Bimbingan karir di sekolah dasar. Jurnal Kajian Ilmu Pendidikan Paedagogi, 4(8).

Tarmidzi. (2011). Pengantar Bimbingan dan Konseling. Medan: Perdana Publishing.

Walgito, B. (2010). Bimbingan dan konseling studi karir. Yogyakarta: CV andi offset. 
